\title{
MSH3 Gene
}

National Cancer Institute

\section{Source}

National Cancer Institute. MSH3 Gene. NCI Thesaurus. Code C20211.

This gene plays a role in DNA mismatch repair and has been implicated in several cancers. 